\title{
Češnjeva listna pegavost, Blumeriella jaapii
}

\section{Nikica OGRIS}

Letošnje leto je precej vlažno. Prav to je razlog, da se je češnjeva listna pegavost pojavila $\mathrm{v}$ pretežnem delu države. Češnjevo listno pegavost povzroča gliva Blumeriella jaapii. V gozdu se pojavlja na divji češnji (Prunus avium), čremsi ( $P$. padus) in rešeljiki $(P$. mahaleb). Bolezen v Sloveniji poznamo že več deset let. Največ težav povzroča $v$ drevesnicah, kjer jo zatirajo s fungicidi in v sadovnjakih na češnjah in višnjah.

Češnjevo listno pegavost smo letos determinirali z mikroskopiranjem pri Godoviču, na Sabotinu in pri Krškem. Na nekaterih mestih je bila intenziteta do 60 \%. Veliko dreves divje češnje je bilo že sredi julija popolnoma brez listja (slika 1 in 2). Če bolezni ne poznaš, lahko pride do napačne razlage, da se je drevo posušilo, pravzaprav pa je drevesu samo prekmalu odpadlo listje.

Bionomija bolezni je naslednja: v začetku junija se na zgornji strani listih pojavijo majhne vijolično-rdeče

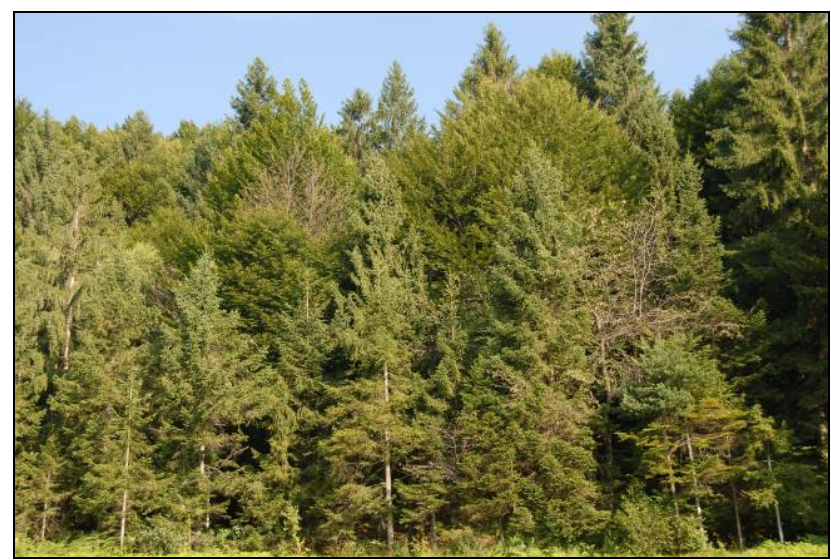

Slika 1: V sestoju od daleč opazimo drevesa brez listja. Ali so se posušila?

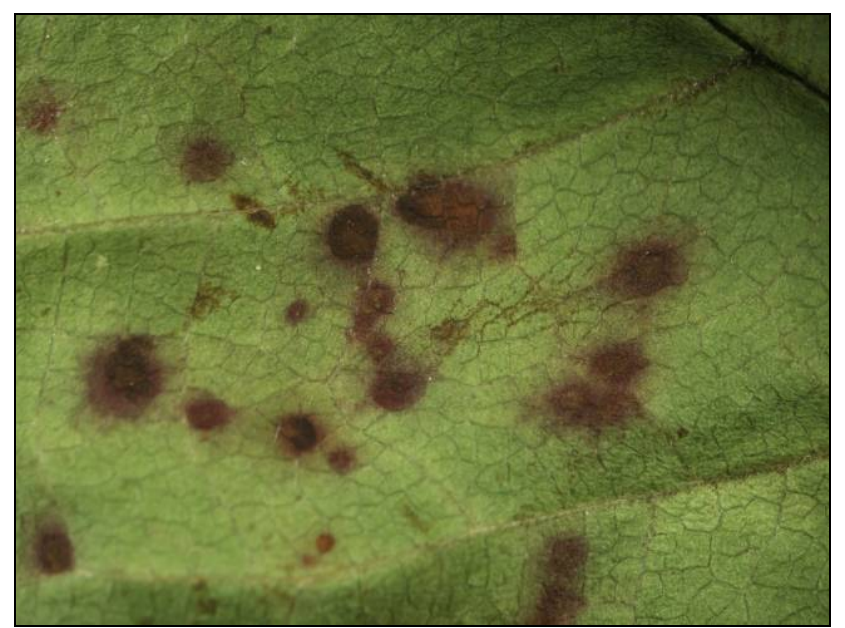

Slika 3: Vijolično-rdeče pege na zgornji strani lista so simptom za češnjevo listno pegavost pege (slika 3). Pege niso ostro razmejene in se postopoma združujejo (slika 4). Listi porumenijo in kmalu odpadejo. Na spodnji strani listov se oblikujejo nespolna trosišča, iz katerih se sproščajo konidiji, ki poskrbijo za širjenje bolezni poleti. Gliva prezimuje v odpadlih listih, iz katerih se spomladi sproščajo bodisi askospore bodisi pomladanski konidiji, ki povzročijo primarne okužbe listov.

Zatiranje bolezni v gozdu ni potrebno, saj je pojav bolezni popolnoma odvisen od vlažnega vremena. Če se bolezen pojavlja leto za letom na istem mestu, lahko pojav bolezni nekoliko omilimo z grabljenjem odpadlih listov pozno poleti ali jeseni. Zaradi zmanjšane primarne produkcije je nekoliko prizadet prirastek v letu, ko je drevesu prekmalu odpadlo listje. Češnjeva listna pegavost je izključno bolezen listov. Zaradi te bolezni se češnji ne posušijo poganjki ali veje. Spomladi se bo češnja ponovno normalno olistala.

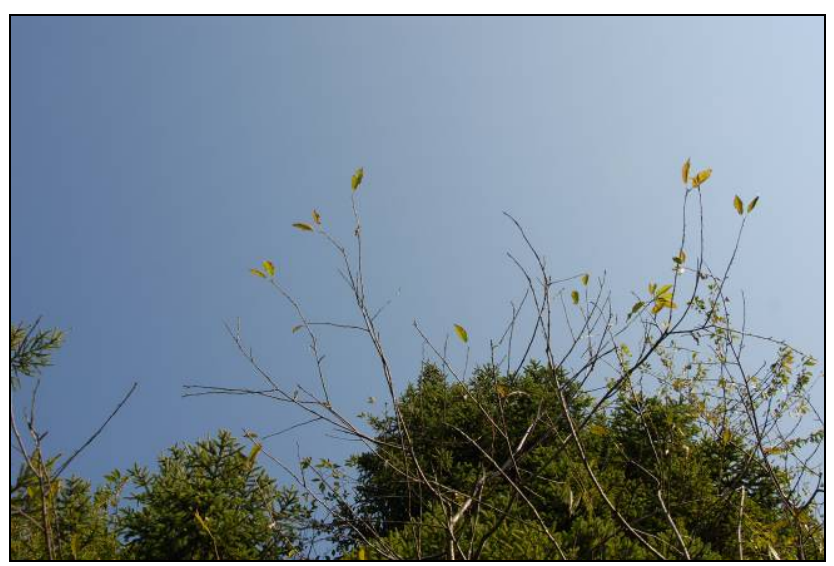

Slika 2: Od blizu vidimo, da gre za divjo češnjo, ki je že sredi julija skoraj popolnoma brez listja

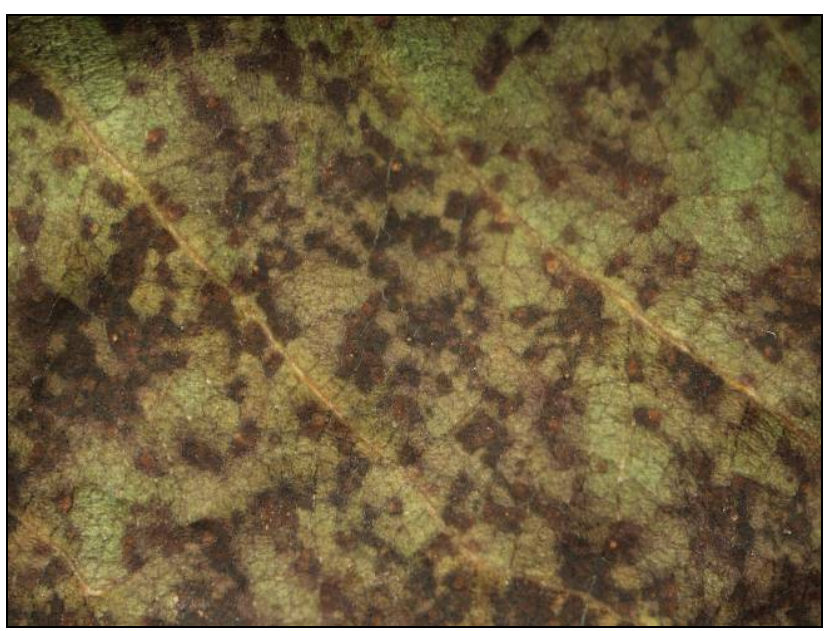

Slika 4: Pege se postopoma združujejo, listi porumenijo in odpadejo 